\title{
Strategi Pemasaran dalam Pencapaian Target Produk Simpanan Pada BRI Syari'ah
}

\author{
Eni Kusrini \\ Fakultas Ekonomi dan Bisnis Islam IAIN Kudus \\ enikusrini50@yahoo.com
}

\begin{abstract}
The achievement of the savings product target obtained is based on the optimism of BRI Syari'ah employees that the majority of Demak people are Muslims who certainly want a trustworthy service in accordance with their beliefs. In addition, BRI Syari'ah's market share in Demak is increasingly providing opportunities to help customers' needs. This study aims to find out: (1) strategies to achieve the target of marketing savings products at Bank Rakyat Indonesia (BRI) Syari'ah in Demak; (2) and analyze the implementation of efforts to implement strategic analysis on savings products at Bank Rakyat Indonesia (BRI) Syari'ah in Demak. This research is expected to provide various benefits. Theoretically, it is useful in the development of Islamic economics related to shari'ah banking, especially the strategy analysis and achievement of its savings targets. Practically beneficial for practitioners, especially for deposit product managers, as a consideration for managing savings products in shari'ah banking in order to achieve the expected targets.
\end{abstract}

Keywords: Strategy, Marketing, Savings Products

\begin{abstract}
Abstrak
Pencapaian target produk simpanan yang diperoleh didasari atas rasa optimis para pegawai BRI Syari'ah bahwa masyarakat Demak mayoritas beragama Islam yang pastinya menginginkan pelayanan yang amanah sesuai dengan kepercayaannya. Selain itu, pangsa pasar BRI Syari'ah di Demak yang semakin memberikan peluang dalam membantu kebutuhan nasabah. Penelitian ini bertujuan untuk mengetahui : (1) strategi pencapaian target pemasaran produk simpanan pada Bank Rakyat Indonesia (BRI) Syari'ah di Demak; (2) dan menganalisis implementasi upaya menerapkan analisis strategi pada produk simpanan pada Bank Rakyat Indonesia (BRI) Syari'ah di Demak. Penelitian ini diharapkan dapat memberikan berbagai manfaat. Secara teoritis, bermanfaat dalam pengembangan ilmu ekonomi Islam berkaitan dengan perbankan syari'ah, khususnya analisis strategi dan pencapaian target simpanannya. Secara praktis bermanfaat bagi praktisi khususnya bagi pengelola produk simpanan, sebagai pertimbangan untuk mengelola produk simpanan di perbankan syari'ah supaya tercapai target yang diharapkan.
\end{abstract}

Kata Kunci : Strategi, Pemasaran, Produk Simpanan

\section{PENDAHULUAN}

Keinginan umat Islam Indonesia akan adanya bank yang beroperasi sesuai dengan prinsip-prinsip syari'at Islam sudah sejak lama digagas oleh para tokoh dan cendekiawan muslim Indonesia. Gagasan 
mendirikan bank yang sejalan dengan prinsip-prinsip ekonomi Islam tersebut sudah mulai ada. Pada tahun 1937, K.H. Mansur, Ketua PP Muhamadiyah periode 1937-1944, mengemukakan pendapatnya tentang keharaman menggunakan jasa perbankan konvensional bagi umat Islam. Ketika itu, ia sudah memunculkan gagasan mengenai pendirian bank Islam di Indonesia (Faza, Iqbal, Muhammad, 2013:22). Gagasan ini berorientasi pada kemaslahatan ummat, dalam operasionalnya bank syari'ah juga memperoleh laba (Profit) atau sering disebut dengan istilah bagi hasil. Perolehan bagi hasil bukan hanya untuk kepentingan pemilik atau pendiri saja, tetapi juga sangat penting untuk pengembangan bank syari'ah. Laba bank syari'ah terutama diperoleh dari selisih antara pendapatan atas penanaman dana dan biaya-biaya yang dikeluarkan selama periode tertentu. Perolehan hasil yang maksimal, bank syari'ah perlu adanya tuntutan untuk pengelolaan dananya secara efisien dan efektif, baik atas dana-dana yang dikumpulkan dari masyarakat (dana pihak ketiga), serta modal pemilik/pendiri bank syari'ah maupun atas pemanfaatan atau penanaman dana tersebut (Muhamad, 2014: 521).

Perlu adanya promosi produk simpanan serta diferensiasi pemasaran guna membangun strategi dan membedakan pemasaran antara BRI Syari'ah di Demak dengan perbankan lainnya. Hal ini bertujuan agar para nasabah akan menerima dan merasa puas terhadap produk simpanan yang ada, sehingga loyalitas nasabah dapat dipertahankan guna mencapai target, keunggulan bersaing, efisiensi serta efektivitas kerja khususnya pada program pemasarannya (Rangkuti Freddy, 2006: 50).

Pendekatan yang digunakan untuk menghadapi segala tantangan dan persaingan yaitu SWOT. Analisis SWOT merupakan sebuah bentuk analisa situasi dan kondisi yang bersifat deskriptif (memberi suatu gambaran). Analisa ini menempatkan situasi dan juga kondisi sebagai faktor masukan, lalu kemudian dikelompokkan menurut kontribusinya masing-masing. Satu hal yang perlu diingat baik-baik oleh para pengguna analisa ini, bahwa analisa SWOT ini semata-mata sebagai suatu analisa yang ditujukan untuk menggambarkan situasi yang sedang dihadapi, dan bukan sebuah alat analisa ajaib yang mampu memberikan jalan keluar yang bagi permasalahan yang sedang dihadapi. Bermanfaat sekali untuk melihat suatu topik ataupun suatu permasalahan dari 4 (empat) sisi yang berbeda. Hasil dari analisa biasanya berupa arahan ataupun rekomendasi untuk mempertahankan kekuatan dan untuk menambah keuntungan dari segi peluang yang ada, sambil mengurangi kekurangan dan juga menghindari ancaman. Jika digunakan dengan benar, analisis ini akan membantu untuk melihat sisi-sisi yang terlupakan atau tidak terlihat selama ini. Analisis ini berperan sebagai alat untuk meminimalisasi kelemahan yang terdapat dalam suatu perusahaan atau organisasi serta 
menekan dampak ancaman yang akan timbul dan tetap harus dihadapi dan diselesaikan. (http://www.pengertianku.net/2015/03/pengertiananalisis-swot-dan-manfaatnya.html, diakses pada tanggal 08 Maret 2016).

\section{KAJIAN TEORITIS}

Bank Syariah adalah bank yang operasi dengan tidak mengandalkan pada bunga. Bank syari'ah atau sering disebut bank tanpa bunga adalah lembaga keuangan atau perbankan yang operasional dan produknya dikembangkan berlandaskan Al Qur'an dan Hadits Nabi SAW, dengan kata lain bank syari'ah adalah lembaga keuangan yang usaha pokoknya melayani simpanan dan pembiayaan dan jasa-jasa lainnya dalam lalu lintas pembayaran serta peredaran uang yang pengoperasiannya disesuaikan dengan prinsip syari'at Islam (Muhamad, 2011: 16).

BRI Syari'ah di Demak merupakan unit cabang dari BRI Syari'ah di Semarang yang sekaligus merupakan kantor pusatnya. BRI Syari'ah ini memiliki tujuan menjadi bank ritel modern terkemuka dengan berbagai ragam produk dan layanan perbankan syari'ahyang sesuai dengan tuntutan masyarakat muslim di Kabupaten Demak. Tujuan ini perlu adanya suatu konsep keutuhan terkait dengan manajemen sebagai suatu sistem. Adapun unsure yang tepat dalam pelaksanaannya meliputi perencanaan, pengorganisasian, pelaksanaan, dan pengawasan. Sebagaimana firman Allah Qs. Al Hasyr (59:18) yaitu :

"Wahai orang-orang yang beriman bertaqwalah kepada Allah dan rencanakanlah masa depanmu. Dan bertaqwalah kepada Allah, sesungguhnya Allah maha tahu atas apa-apa yang kalian perbuat".

Suatu perencanaan yang baik harus dilakukan melalui berbagai proses kegiatan yang meliputi forecasting, objective, polices, programmes, schedules, procedures, dan budget. Proses kegiatan tersebut harus dipadukan dengan sistem organisasi yang berkompeten serta memiliki tujuan yang sama dalam memajukan perbankan syari'ah yang ada, khususnya pada produk simpanan pada BRI Syari'ah yang ada di Demak.

\section{Produk Simpanan Syari'ah}

Produk simpanan syari'ah merupakan simpanan yang berdasarkan akad wadiah atau investasi dana berdasarkan akad mudharabah atau akad lain yang tidak bertentangan dengan prinsip syariahyang penarikannya hanya dapat dilakukan menurut syarat dan ketentuan tertentu yang disepakati, tetapi tidak dapat ditarik dengan cek, bilyet giro, dan atau alat lainnya yang dipersamakan dengan itu (Undang-Undang No. 21 Tahun 2008). Adapun teori lain tentang produk simpanan syari'ah yaitu Produk tabungan yang dibenarkan atau diperbolehkan secara syariah adalah 
tabungan yang berdasarkan prinsip mudharabah dan wadiah, sehingga kita mengenal tabungan mudharabah dan tabungan wadiah (Fatwa Nomor 02/DSN-MUI/IV/2000).

Tabungan mudharabah merupakan tabungan yang dijalankan dalam dua bentuk, yakni mudharabah mutlaqoh dan mudharabah muqayyadah. Bank syariah bertindak sebagai mudharib dan nasabah sebagai shahibul mal. Bank syariah dalam kapasitasnya sebagai mudharib, mempunyai kuasa untuk melakukan berbagai macam usaha yang tidak bertentangan dengan prinsip Syariah serta mengembangkannya, termasuk melakukan akad mudharabah dengan pihak lain. Wadiah yadh adh dhamanah ini mempunyai implikasi hukum yang sama dengan qardh, maka nasabah menitipkan dan bank tidak boleh saling menjanjikan untuk membagihasilkan keuntungan harta tersebut. Bank diperkenankan memberikan bonus kepada pemilik harta titipan selama tidak disayaratkan di muka. Kebijakan bank syariah semata yang bersifat sukarela (https:/ / aprizal27.wordpress.com/2011/10/20/tabungan-syariah/, diakses pada tanggal 25 Juli 2016).

\section{Strategi Pemasaran}

Strategi pemasaran adalah suatu kegiatan menyeleksi dan penjelasan suatu atau beberapa target pasar dan mengembangkan serta memelihara suatu bauran pemasaran yang akan menghasilkan kepuasan konsumen dengan pasar yang dituju, dimana dalam menentukan strategi pemasaran yang sesuai tiga tahapan yaitu Segmentation (Segmentasi Pasar), Targeting (Penentuan Posisi Pasar), Positioning (Strategi Memasuki Pasar), serta marketing mix (bauran pemasaran). Dalam bauran pemasaran terdapat ada $4 P$ yang utama yaitu Product, Price, Place dan Promotion. Productmerupakan usaha yang dijalankan, price merupakan harga yang ditentukan, place merupakan tempat usaha, dan promotion merupakan upaya yang dilakukan dalam mencapai keberhasilan pemasarannya. Akan tetapi semua itu lebih sempurna lagi bila ditambah dengan 3P dalam bauran pemasaran yaitu People, Process, dan Physical Evidence (Firmansyah, dan Abdilah, 2014:81).

Bentuk organisasi bisnis dalam perekonomian perbankan syari'ah meliputi pertama perusahaan perorangan (Sole Proprietorship) merupakan format organisasi bisnis yang paling sederhana yang hampir ada di setiap sistem ekonomi non sosialis, dan merupakan bentuk usaha pelaksanaan bisnis yang tertua, sistem ekonomi Islam mengizinkan perusahaan swasta (private enterprize) yang dikelola oleh individu dan tidak mengikat mereka secara khusus. Usaha dan bisnis yang dijalankan hanya terikat syari'ah Islam dan prinsip yang ditentukan oleh hukum yang ada. Kedua persekutuan atau syirkah (partnership), yaitu suatu hubungan antara dua orang atau lebih untuk mendistribusikan laba 
(profit) atau kerugian (losses) dari suatu bisnis atau usaha yang dijalankan oleh seluruhnya atau salah satu dari mereka sebagai pengelola atas yang lain. Ketiga mudharabah, yaitu suatu hubungan dua orang atau lebih dimana salah satu pihak menyediakan modal (investor) kepada pihak lain yang berkedudukan sebagai pengeloa (mudharib) untuk menjalankan suatu bisnis dengan kesepakatan untuk mendapatkan tingkat keuntungan tertentu. Keberadaan perbankan Islam di tanah air telah mendapatkan pijakan kokoh setelah lahirnya Undang-Undang Perbankan Nomor 7 tahun 1992 yang direvisi melalui Undang-Undang nomor 10 Tahun 1998, yang dengan tegas mengakui keberadaan dan berfungsinya bank bagi hasil atau bank Islam.

\section{Pemasaran}

Pemasaran adalah suatu proses kegiatan yang dipengaruhi oleh berbagai faktor sosial, budaya, politik, ekonomi, dan manjerial. Akibat dari pengaruh berbagai faktor tersebut adalah masing-masing individu maupun kelompok mendapatkan kebutuhan dan keinginan dengan menciptakan, menawarkan, dan menukarkan produk yang memiliki nilai komoditas (Rangkuti, Freddy, 1997: 101).

\section{Karakteristik Pemasaran Islami (syariah marketer)}

Sebagai panduan bagi para pemasar yang pertama teistis (rabbaniyyah) Salah satu ciri khas pemasaran pada BRI Syari'ah di Demak yaitu sifat yang religius (di niyyah). Kondisi ini berangkat dari kesadaran akan nilai religius, yang dipandang penting dan mewarnai aktivitas pemasaran. Kedua jiwa seorang syariah marketer pada BRI Syari'ah di Demak yang meyakini bahwa Allah SWT selalu dekat dan mengawasinya serta meminta pertanggung jawaban ketika dia sedang melaksanakan segala macam bentuk bisnis. Ketiga etis (akhlaqiyyah) sifat etis yang ada pada BRI Syari'ah di Demak merupakan turunan dari sifat teistis. Keempat realistis (Al-Waqi 'iyyah) syariah marketing bukanlah konsep yang eksklusif, fanatis, anti-modernitas. Syariah marketer adalah konsep pemasaran yang fleksibel, sebagaimana keluwesan syariah Islamiyah yang melandasinya(http:/ / makalahqsyamlah.blogspot.co.id/2012/06/manaje men-pemasaran-islam.html, diakses pada tanggal 04 Maret 2016).

Kelima humanistis (insa'niyyah) bahwa syariah diciptakan untuk manusia agar derajatnya terangkat, sifat kemanusiaannya terjaga dan terpelihara, serta sifat-sifat kehewanannya dapat terkekang dengan panduan syariah. Dengan memiliki nilai humanistis ia menjadi manusia yang terkontrol, dan seimbang (tawazun), bukan manusia yang serakah, yang menghalalkan segala cara untuk meraih keuntungan yang sebesarbesarnya. Syariat Islam adalah syariah humanistis (insaniyyah). Syariat Islam diciptakan untuk manusia sesuai dengan kapasitasnya tanpa 
menghiraukan ras, warna kulit, kebangsaan, dan status. Hal inilah yang membuat syariah memiliki sifat universal sehingga menjadi syariat humanistis universal.

\section{Strategi Pencapaian Target Pemasaran Produk Simpanan Pada BRI Syari'ah Di Demak.}

Strategi merupakan tujuan jangka panjang dari suatu perusahaan, serta pendayagunaan dan alokasi semua sumber daya yang penting untuk mencapai tujuan tersebut (Rangkuti, Freddy, 1997: 4). Jadi strategi merupakan cara cerdas dalam menganalisis keadaan perbankan syari'ah yang ada. Strategi yang diterapkan oleh BRI Syari'ah di Demak yaitu melibatkan unsur-unsur strategi persaingan yang meliputi segmentasi pasar, targeting, dan positioning.

\section{Penerapan Analisis SWOT Terhadap Pencapaian Target Produk Simpanan Pada BRI Syari'ah Di Demak}

Analisis SWOT yang digunakan adalah dengan kriteria kekuatan, kelemahan, peluang, dan ancaman. Maka yang dilakukan terlebih dahulu adalah menganalisis pencapaian target simpanan selama lima tahun terakhir pada BRI Syari'ah di Demak. Adapun data pencapaian targetnya bahwa pada awal mula berdirinya BRI Syari'ah di Demak, realita dari produk simpanan (tabungan impian, tabungan deposito, tabungan haji, dan tabungan faedah) hanya mencapai Rp. 1,5 milyar sekitar $10 \%$ dari target yang diharapkan, pada tahun kedua realita produk simpanan hanya mencapai Rp. 3 milyar sekitar 20\% dari target yang diharapkan, pada tahun ketiga realita produk simpanan mencapai Rp. 7,7 milyar sekitar 51,3 \% dari target yang diharapkan dan pada tahun keempat realita produk simpanan sudah mulai mendekati target yang diharapkan, yaitu Rp. 13,8 milyar sekitar 92 \% dari target yang diharapkan. Meskipun belum bisa mencapai target yang diharapkan. Hal ini disebabkan oleh lemahnya penguasaan pangsa pasar. Selain itu juga disebabkan kurangnya pengalaman Manajemen Sumber Daya Manusia (MSDM), mengingat masih kondisi awal berdirinya BRI Syari'ah di Demak ini. Kurangnya tenaga marketing juga menyebabkan lambannya informasi produk simpanan untuk bisa dikenal masyarakat Demak. Selanjutnya pada tahun kelima, meskipun belum pada laporan pembukuan akhir, realita produk simpanan pada bulan April 2016 sudah mencapai 19,4 milyar berarti sudah melebihi target yang diharapkan, artinya target produk simpanan di tahun ini sangat signifikan sekali peningkatannya, sehingga mampu melampaui target yang diharapkan. Pada tahun 2017 dan 2018 target simpanan sebesar 16 Milyar, realita simpanan mencapai 20,4 Milyar. 
Pada tahun 2012 jenis produk terdiri dari tabungan impian belum ada minat nasabah, tabungan deposito Rp. 800 juta, tabungan haji Rp. 100 juta, dan tabungan faedah Rp. 600 juta. Target pada tahun 2012 ini sebesar Rp. 15 milyar, jumlah keseluruhan realita Rp. 1,5 milyar berarti sekitar 10 $\%$ dari realita. Pada tahun ini adalah awal dari pengenalan produk simpanan syari'ah pada BRI Syari'ah di Demak, sehingga masih mempelajari keadaan pangsa pasar yang ada. Pada tahun 2013 jenis produk simpanan terdiri dari tabungan impian Rp. 10 juta, tabungan deposito Rp. 1,5 milyar, tabungan haji Rp. 250 juta, dan tabungan faedah Rp. 1,25 milyar. Target pada tahun 2013 ini sebesar Rp. 15 milyar, jumlah keseluruhan realita Rp. 3 milyar berarti sekitar $20 \%$ dari realita. Pada tahun kedua berdirinya BRI Syari'ah ini mulai terlihat sudah ada perkembangan minat nasabah terhadap produk simpanan pada BRI Syari'ah di Demak ini. Realita peningkatan produk simpanan ini naik dari $10 \%$ menjadi $20 \%$.

Pada tahun 2014 jenis produk simpanan terdiri dari tabungan impian Rp. 25 juta, tabungan deposito Rp. 2 milyar, tabungan haji Rp. 1,5 milyar, dan tabungan faedah Rp. 4,25 milyar. Target pada tahun 2014 ini sebesar Rp. 15 milyar, jumlah keseluruhan realita Rp. 7,7 milyar berarti sekitar 51,3\% dari realita. Pada tahun ini masyarakat di Demak sudah mulai menerima kehadiran BRI Syari'ah sehingga nasabah mulai berangsur-angsur meningkat $21,3 \%$ dari tahun sebelumnya. Pihak BRI Syari'ah mulai optimis bahwa keberadaannya mampu memberikan peluang yang baik terhadap pelayanan nasabah.

Pada tahun 2015 jenis produk simpanan terdiri dari tabungan impian Rp. 50 juta, tabungan deposito Rp. 3,5 milyar, tabungan haji Rp. 3,5 milyar, dan tabungan faedah Rp. 6,75 milyar. Target pada tahun 2015 ini sebesar Rp. 15 milyar, jumlah keseluruhan realita Rp. 13,9 milyar berarti sekitar $92 \%$ dari realita. Perkembangan peminat produk simpanan pada BRI Syari'ah di Demak ini akhirnya dari tahun 2012 sampai tahun 2015 mulai mendekatitarget yang diharapkan. Peningkatannya mencapai $41 \%$ dari tahun 2014. Nasabah mulai bertambah banyak memberikan kepercayaan pada BRI Syari'ah.

Pada tahun 2016 jenis produk simpanan terdiri dari tabungan impian Rp. 56 juta, tabungan deposito Rp. 3,5 milyar, tabungan haji Rp. 6,9 milyar, dan tabungan faedah Rp. 8,9 milyar. Target pada tahun 2016 ini sebesar Rp. 15 milyar, jumlah keseluruhan realita Rp. 19,4 milyar berarti dari realita ini sudah melebihi target yang diharapkan. Tahun ini adalah target yang sangat luar biasa mengingat baru lima bulan berjalan sudah melebihi target yang ditentukan. Dalam kurun waktu lima tahun BRI Syari'ah di Demak benar-benar mampu tumbuh dan berkembang pesat sesuai perkembangan zaman sehingga nasabah merasa benar-benar 
nyaman menggunakan jasanya. (Hasil Penelitian Pada BRI Syariah Demak, pada 13 April 2016).

\section{Strategi analisis SWOT}

Strategi dengan menggunakan Analisis SWOT pada BRI Syari'ah di Demak dapat dijelaskan bahwa IFAS adalah Internal Strategic Factors Analysis Summary, yaitu faktor-faktor strategis internal PT. BRI Syari'ah. Sedangkan EFAS adalah Internal Strategic Factors Analysis Summary, yaitu faktor-faktor strategi eksternal suatu perusahaan. Perbandingan keduanya dapat menghasilkan alternatif strategi $(S O, S T, W O$, dan $W T)$.

\section{Kekuatan (Strenght)}

Kekuatan (Strenght) merupakan situasi atau kondisi dari kekuatan organisasi atau program pada saat ini. Bank Rakyat Indonesia (BRI) Syari'ah di Demak memberikan kepercayaan kepada nasabah dengan kekuatan yang ada seperti letaknya Lokasi BRI Syariah Demak, Strategis, produk simpanan syari' ah unggulan

Satu-satunya di Demak, menggunakan sistem bagi hasil yang menguntungkan kedua belah pihak.

Bagi hasil $/$ bulan $=$ Nisbah $(30 \%) \times 365$ hari $\times$ Saldo $-20 \%$ pajak

$$
12365 \text { hari }
$$

Tabungan Deposito

Bagi hasil $/$ bulan $=$ Nisbah $(58 \%) \times$ Saldo $\times$ Equivalent $(0,12027178) \times 30$

365-20\% (Pajak Simpanan)

Tabungan Haji

Bagi hasil/bulan = Nisbah $(15 \%) \times 365$ hari $\times$ Saldo $-20 \%$ pajak $12 \times 365$ hari

Tabungan Faedah

Bagi hasil yang diberikan berupa bonus, disesuaikan dengan besar kecilnya tabungan (Data Hasil Wawancara dengan Bapak Samsul Rizal Selaku Pegawai Bagian Brand Operation Spv dan MSDM BRI Syari'ah Demak, pada tanggal 15 April 2016).

Cost of Capital bertahap dari tahun 2012 sampai dengan tahun 2018 mengalami pertambahan yang cukup signifikan sesuai data pencapaian target, akses informasi dan regulasi Informasi sudah mulai mudah didapatkan melalui internet dan brosur, sarana dan prasarana sesuai dengan setiap operasional kerja yang dijalankan, seperti tersedianya lebih dari 10 (sepuluh) komputer dan printer. Sehingga proses pelayanan menjadi tepat, sumber Daya Manusia (SDM) muda dan berpotensi, sesuai bidangnya. Teknologi informasi e-Channel yang baik, dan masyarakat Demak mayoritas muslim, 


\section{Kelemahan (Weaknesses)}

Kelemahan (Weaknesses) merupakan situasi atau kondisi dari kelemahan organisasi atau program pada saat ini.Kelemahan yang ada pada BRI Syari'ah di Demak saat ini yaitu tidak memiliki kantor cabang lain, hal ini sulit untuk menjangkau nasabah yang ada di desa-desa terpencil wilayah Demak, terutama bagi nasabah yang tidak bisa internet dan mengendarai kendaraan bermotor. Mitra kerja bisnis belum optimal, produk tabungan masih fluktuatif secara data pada target produk simpanan, minimnya tenaga marketing, manajemen pelayanan yang kurang,

\section{Peluang (Opportunities)}

Peluang (Opportunities) merupakan situasi atau kondisi dari peluang di luar organisasi dan memberikan peluang berkembang bagi organisasi di masa depan. Peluang yang dimilki BRI Syari'ah di Demak yaitu pangsa pasar potensial, dukungan pemerintah, kerjasama dengan instansi/lembaga pemerintah/masyarakat

\section{Ancaman (Treaths)}

Ancaman (Treaths) merupakan situasi yang memberikan ancaman bagi organisasi yang datang dari luar organisasi dan dapat mengancam eksistensi organisasi di masa depan, seperti ketidakpastian dana simpanan, kompetisi antar bank konvensional,

\section{SO (Strenght- Opportunities)}

Strategi SO (Strenght- Opportunities)merupakan strategi yang menggunakan kekuatan untuk menciptakan dan memanfaatkan peluang pada BRI Syari'ah di Demak. Langkah-langkahnya yaitu memperluas bauran pemasaran, Positioning pasar, target market yang tepat, pembaharuan perubahan desain produk sesuai zaman, karena dirancang untuk mewujudkan impian nasabahnya (kurban, pendidikan, liburan, belanja) dengan terencana memakai mekanisme autodebet setoran rutin bulanan.Akadnya mudharabah muthlaqah. Promo produk lewat iklan.

\section{WO (Weaknesses-Opportunities)}

Strategi WO (Weaknesses-Opportunities) merupakan strategi yang untuk meminimalkan kelemahan dan memanfaatkan peluang yang ada pada BRI Syari'ah di Demak. Langkah-langkahnya yaitu meningkatkan kerjasama untuk peningkatan target, sistem kinerja organisasi yang baik, membuka cabang-cabang lain di setiap kecamatan, menambah jenis produk simpanan.

\section{ST (Strenght- Treaths)}

Strategi ST (Strenght- Treaths) merupakan strategi yang menggunakan kekuatan untuk mengatasi ancaman yang ada. Langkah-langkahnya yaitu 
membuka produk pelayanan lainnya yang dapat digunakan untuk pembayaranlainnya, dan dapat terakses ke berbagai Negara. Meningkatkan kepercayaan masyarakat muslim dengan adanya keterlibatan BRI Syari'ah di Demak dengan acara keagamaan yang ada, seperti santunan anak yatim, zakat, infaq, maupun shodaqoh.

\section{Secara WT (Weaknesses- Treaths)}

Strategi WT (Weaknesses- Treaths) merupakan strategi yang meminimalkan kelemahan dan menghindari ancaman yang berasal dari pesaing, seperti memperkuat eksistensi perbankan syari'ah, bergerak cepat mendahului pesaing (Hasil Penelitian pada BRI Syariah Demak, pada 13 April 2016) .

\section{KESIMPULAN}

Strategi pemasaran dengan menggunakan analisis SWOT yang diterapkan pada BRI Syari'ah di Demak merupakan suatu cara untuk menciptakan kemajuan dan peningkatan pemasaran produk simpanan dalam pencapaian target yang diharapkan. Sehingga pada penelitian ini mampu menjadi solusi penyelesaian permasalahan yang akan datang. Terlebih lagi peran perbankan syari'ah mampu menjadi operasional pada Masyarakat Ekonomi Asean (MEA). Strategi ini akan mampu menganalisis berbagai aspek pada produk simpanan yang dihadapi BRI Syari'ah di Demak. Analisis SWOT terhadap produk simpanan pada BRI Syari'ah di Demak, secara kekuatan meliputi produk simpanan syari'ah unggulan, sistem bagi hasil, cost of capital, informasi dan regulasi lengkap, sarana dan prasarana yang mendukung, SDM yang berpotensi, dan memiliki teknologi e-channel. Secara kelemahan meliputi keterbatasan kantor, terbatasnya mitra kerja, minat nasabah rendah, terbatasnya tenaga marketing, pelayanan kurang maksimal, letaknya kurang strategis. Secara peluang meliputi pangsa pasar potensial, mayoritas masyarakat muslim, dukungan pemerintah, satu-satunya produk simpanan syari'ah, dan parthnership luas. Secara ancaman meliputi ketidakpastian jumlah simpanan, kompetisi dengan bank konvensional, minat nasabah rendah, dan pemasaran yang belum maksimal. Dengan adanya analisis SWOT ini, jumlah perolehan nominal produk simpanan pada BRI Syari'ah di Demak akan mengalami peningkatan dan mampu berkembang sesuai fungsi dan kebutuhan masyarakat.

\section{DAFTAR PUSTAKA}

Fasa, Iqbal, Muhammad, 2013, Tantangan dan Strategi Perkembangan Perbankan Syari'ah di Indonesia, Volume 2, Nomor 1, UIN Sunan Kalijaga Yogyakarta. 
Firmansyah, dan Abdilah, 2014, Analisis SWOT Dalam Penentuan Strategi Pemasaran Produk Pembiayaan Pada PT. Panin Bank Syari'ah Tbk, Kantor Cabang Malang, Modernisasi,Volume 10. No.2, UIN Maulana Malik Ibrahim Malang, .

Muhamad, 2011, Manajemen Bank Syari'ah, UPP STIM YKPN, Yogyakarta.

Muhamad, 2014, Manajemen Keuangan Syari'ah, UPP STIM YKPN, Yogyakarta.

Rangkuti, Freddy, 2006, Analisis SWOT Teknik Membedah Kasus bisnis , PT. Gramedia Pustaka Utama, Jakarta.

Rangkuti, Freddy, 1997, ANALISIS SWOT: Teknik Membedah Kasus Bisnis, PT. Gramedia Pustaka Utama, Jakarta.

Fatwa Nomor 02/DSN-MUI/IV/2000

Undang-Undang Perbankan No. 21 Tahun 2008.

Data hasil observasi pada BRI Syari'ah di Demak, tanggal 02 Mei 2016.

Data Hasil Wawancara dengan Bapak Samsul Rizal , Pegawai Bagian Brand Operation Spv dan MSDM BRI Syari'ah Demak, pada tanggal 15 April 2016.

Al Quran, Qs. Al Hasyr (59:18)

http://makalahqsyamlah.blogspot.co.id/2012/06/manajemen-pemasaranislam.html, diakses pada tanggal 06 Maret 2016.

http://www.pengertianku.net/2015/03/pengertian-analisis-swot-danmanfaatnya.html, diakses pada tanggal 08 Maret 2016.

(https://aprizal27.wordpress.com/2011/10/20/tabungan-syariah/, diakses pada tanggal 25 Juli 2016). 
Eni Kusrini

Halaman ini sengaja dikosongkan 